\title{
Zanclea-coral association: new records from Maldives
}
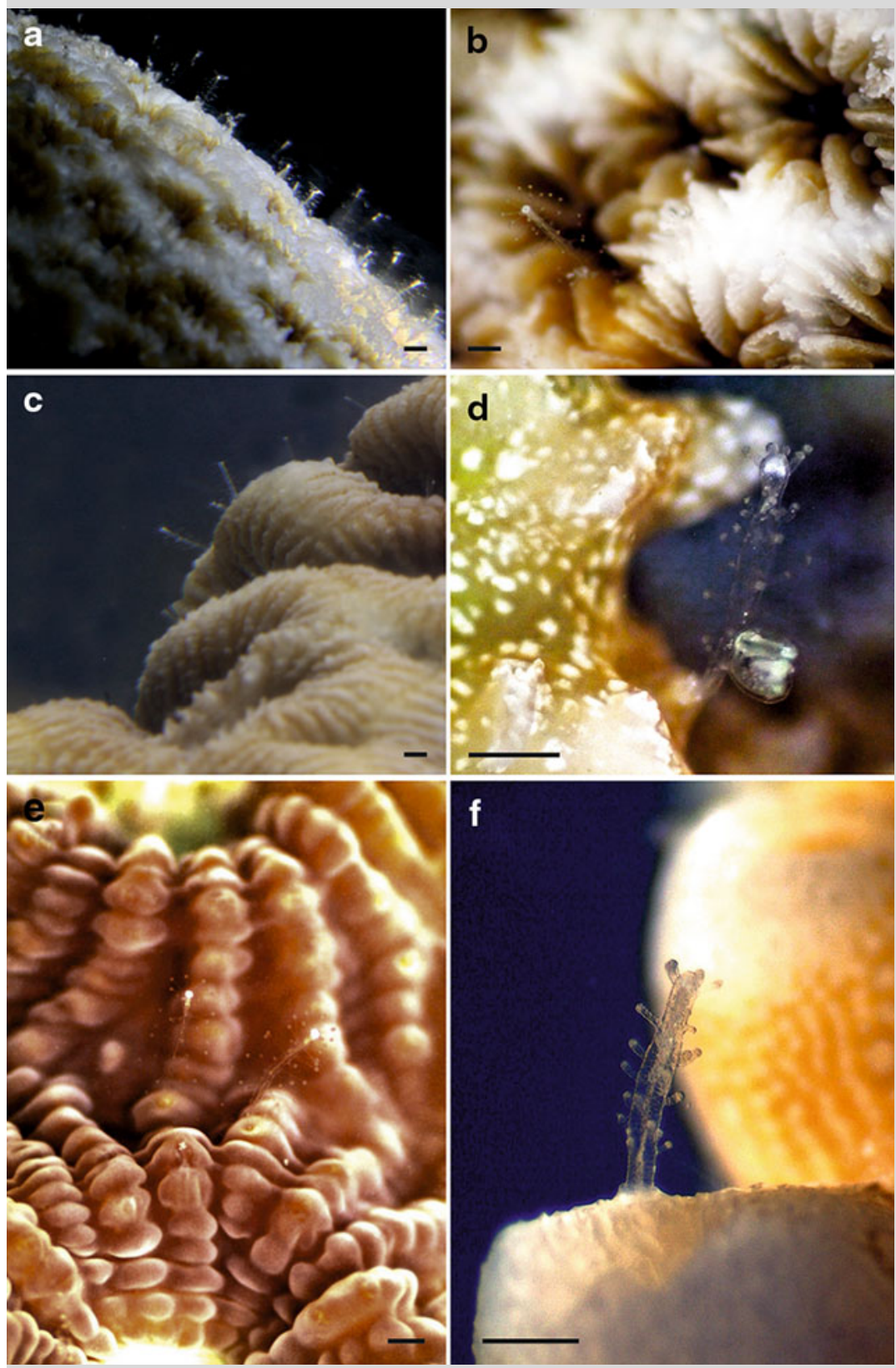

Fig. 1 Some of Maldivian Zanclea-coral associations. Zanclea polyps inhabiting a, b Leptastrea purpurea, c, d Favites halicora, e Favia favus, and f Acropora muricata; (Scale bars: a, c $1 \mathrm{~mm}$; b, d-f $500 \mu \mathrm{m})$
To date, few hydroids have been observed to be associated with anthozoans, and only three Pacific Zanclea species are known to live in symbiosis with scleractinian corals, namely Zanclea gilii, Z. margaritae, and Z. sango (Boero et al. 2000; Pantos and Bythell 2010; Hirose and Hirose 2011). Here, we report the first evidence of this kind of association in the Indian Ocean. During recent expeditions to Magoodhoo Island $\left(3^{\circ} 04^{\prime} \mathrm{N} ; 72^{\circ} 57^{\prime} \mathrm{E}\right.$, Faafu Atoll, Republic of Maldives), numerous Zanclea spp. colonies were observed to live in symbiosis with scleractinians up to about $10 \mathrm{~m}$ depth. Specimens belonging to Zanclea spp. were found not only on Acropora muricata and Pavona sp., which are scleractinians previously known to be involved in this association, but also on coral colonies belonging to Favia favus, Favites halicora, Leptastrea purpurea, Montipora sp., Porites cylindrica, and Symphyllia sp. (Fig. 1a-f). Thus, our results extend the geographic distribution and the host range of this symbiosis, strongly suggesting that associations between hydroids and scleractinians could be much more widespread than previously thought, which is consistent with the scenarios depicted by recent molecular studies (Fontana et al. 2012). The benefits and costs of this symbiosis are still not clear. Although trophic and/or protection mutualism seems a plausible explanation of the relationship, a possible relationship between the occurrence of hydroids and coral diseases has also been proposed (Pantos and Bythell 2010). The potential implications of the hydroid-scleractinian symbiosis for coral health, its wide distribution, and the number of species it involves indicate urgent need for further investigations.

\section{References}

Boero F, Bouillon J, Gravili C (2000) A survey of Zanclea, Halocoryne and Zanclella (Cnidaria, Hydrozoa, Anthomedusae, Zancleidae) with description of new species. Ital J Zool 67:93-124

Fontana S, Keshavmurthy S, Hsieh HJ, Denis V, Kuo C-Y, Hsu C-M, Leung JKL, Tsa W-S, Wallace CC, Chen CA (2012) Molecular evidence shows low species diversity of coral associated hydroids in Acropora corals. PLoS ONE 7(11):e50130. doi:10.1371/journal.pone.0050130

Hirose M, Hirose E (2011) A new species of Zanclea (Cnidaria: Hydrozoa) associated with scleractinian corals from Okinawa, Japan. J Mar Biol Assoc U K 92:877-884 Pantos P, Bythell JC (2010) A novel reef coral symbiosis. Coral Reefs 29:761-770

S. Montano $(\bowtie) \cdot D$. Maggioni · P. Galli · D. Seveso

Department of Biotechnologies and Biosciences, University of Milan-Bicocca, Piazza della Scienza 2, 20126 Milan, Italy

e-mail: simone.montano@unimib.it

S. Puce

Department of Life and Environmental Sciences, Polytechnic University of Marche, Via Brecce Bianche, 60131 Ancona, Italy

Received: 13 December 2012/Accepted: 27 February 2013/Published online: 13 March 2013

Coral Reefs (2013) 32:701

(C) Springer-Verlag Berlin Heidelberg 2013 DOI $10.1007 / \mathrm{s} 00338-013-1023-3$ 